
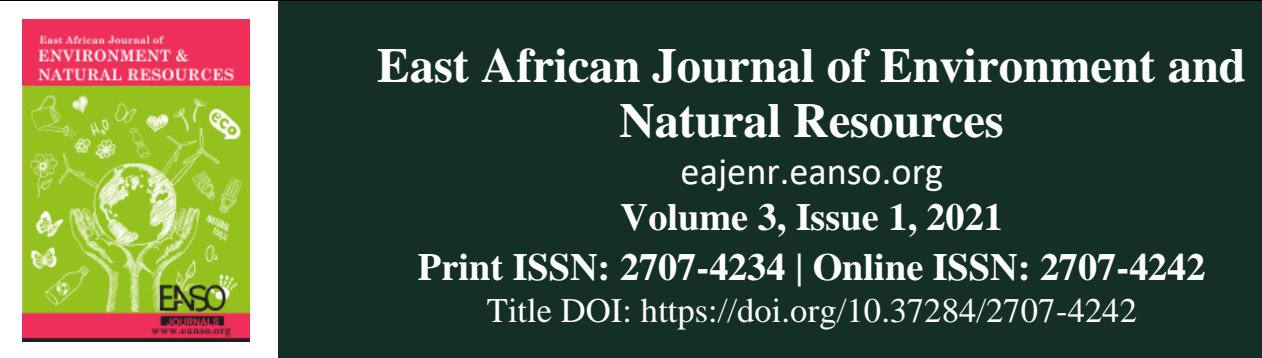

Original Article

\title{
Housing Transformation in Kampala, Uganda: Causes and Opportunities
}

\author{
Stephen Mukiibi, $\mathrm{PhD}^{1^{*}}$ \& Jennifer Nalubwama Machyo ${ }^{1}$ \\ ${ }^{1}$ Department of Architecture and Physical Planning, Makerere University, P. O. Box 7062, Kampala, Uganda. \\ *ORCID: https://orcid.org/0000-0002-4330-2135; Author for Correspondence email: smukbs7@ gmail.com.
}

Article DOI: https://doi.org/10.37284/eajenr.3.1.266

\section{Date Published: ABSTRACT}

08 January 2021 This paper discusses house transformation by owners in Kampala, the capital city of Uganda, examining the reasons for the phenomenon and highlighting its

Keywords: nature, opportunities it offers and what be done to formalise it and take

Owner-Occupied advantage of some of these opportunities for the benefit of the community. The

Housing,

House Transformation,

Dynamic Housing.

main objective of the study was to investigate the factors and processes leading to house transformation in Kampala's owner-occupied houses. The study revealed that the processes of house development and transformation in Kampala are largely informal, excluding professionals and local authorities. House transformations were a means of expression of the changing needs of the owners, in terms of sizes, income, class and status. House transformations are characterised by phased alterations/modifications, which result in more space for the household needs, income generation and house improvement and status uplift. The process being widespread, almost inevitable and addressing the largely genuine concern. The research recommends formalisation of guided house transformation and phased construction by Kampala Capital City Authority (KCCA) under the consultation of house-owners and professionals.

APA CITATION

Mukiibi, S., \& Machyo, J. N. (2021). Housing Transformation in Kampala, Uganda: Causes and Opportunities. East African Journal of Environment and Natural Resources, 3(1), 1-7. https://doi.org/10.37284/eajenr.3.1.266

\section{CHICAGO CITATION}

Mukiibi, Stephen, and Jennifer Nalubwama Machyo. 2021. "Housing Transformation in Kampala, Uganda: Causes and Opportunities". East African Journal of Environment and Natural Resources 3 (1), 1-7. https://doi.org/10.37284/eajenr.3.1.266.

\section{HARVARD CITATION}

Mukiibi, S. and Machyo, J. N. (2021) "Housing Transformation in Kampala, Uganda: Causes and Opportunities”, East African Journal of Environment and Natural Resources, 3(1), pp. 1-7. doi: 10.37284/eajenr.3.1.266. 


\section{IEEE CITATION}

S. Mukiibi, and J. N. Machyo, "Housing Transformation in Kampala, Uganda: Causes and Opportunities", EAJENR, vol. 3, no. 1, pp. 1-7, Aug. 2021.

\section{MLA CITATION}

Mukiibi, Stephen, and Jennifer Nalubwama Machyo. "Housing Transformation in Kampala, Uganda: Causes and Opportunities". East African Journal of Environment and Natural Resources, Vol. 3, no. 1, August 2021, pp. 1-7, doi:10.37284/eajenr.3.1.266.

\section{INTRODUCTION}

Studies of house transformation have been carried out largely on public housing that is assumed to be developed with minimal involvement of the occupants or owners as this tends to affect the latter's satisfaction of the houses they occupy (Nguluma, 2003). In Uganda, house transformations take place both in ownerdeveloped housing and public housing in similar ways. In Uganda, households are largely responsible for the construction of their houses. They do so using the limited resources to meet their housing needs. Many households, especially those living in slum environments and informal settlements have limited, intermittent incomes while engaged in informal employment.

Access to mortgages to raise housing finance is a challenge to those not employed in the formal sector because of the restrictive eligibility requirements. In an environment of increasing housing demand, low housing affordability, limited employment opportunities and intermittent incomes many households construct their houses incrementally, extending and/or altering them as need and means arise (Mukiibi, 2020; Beattie, Mayer \& Yildirim, 2010). Nguluma (2003) observed similar situations in the slum of Hanna Nassif in Dar-es-Salaam, Tanzania, where the socio-economic environment is not very different from that found in other sub-Saharan African cities, Kampala inclusive. Both tenants and property owners carry out extensions and alterations when occupying the dwelling unit, indicating that the transformations are part of the settlement's growth.

Tipple (1999a) describes house transformation as changes and extensions to dwellings made by occupants of housing for their own use or for renting out. A number of researchers have largely observed and studied house transformation in public housing (Popkin, Cunningham and Burt, 2005; Tipple, 1999a; Gosling, Keogh and Stabler, 1993). Popkin et al. (2005) observe that house transformation in America is fundamentally for residents of severely distressed public housing and hard-to-house residents. The interest to transform houses is a desire for many homeowners in many countries. When analysing strategies to individualise home modifications for older people in America, Barry (2008) found that many senior homeowners would like to make modifications to their houses as they age but are constrained by lack of knowledge, lack of money and distrust of contractors as some of the factors hindering them from making such changes.

While studying the process of housing transformation in Iran, Mirmoghtadaee (2009) found that development and urbanisation were major drivers of house transformation, leading to the gradual replacement of individual houses with residential multifamily complexes and apartments. Tipple (1999a) examines user-initiated transformations to government-built housing in Bangladesh, Egypt, Ghana and Zimbabwe and observes that low-income households supply new rooms and services both to improve their housing conditions and to supply rental accommodation for family members living rent-free. Studies in Lagos, Nigeria, observed that residents of housing schemes in the city were more satisfied with the building design features and least satisfied with the physical environment of the estates (Aduwo et al., 2013). When examining the transformation of dwellings in public housing in Lagos, Aduwo et al. (2013) conclude that spontaneous house transformation activities can be minimised by giving adequate attention to the design of main activity areas in the dwelling units, and by promoting a core housing strategy.

Studying transformations in developing countries, Tipple (1999b) maintains that most planning 
authorities seem at best only tolerant of, and at worst totally opposed to, the extensions. Tipple (1999b) further argues that housing transformations are helpful in conditions of serious housing needs as they improve occupancy rates and space, and increase the supply of housing. Kallus and Dychtwald (2010) contend that housing transformations are required for dwellings that do not conform to technological requirements, social conventions, changes in familial or socio-economic circumstances, or for occupants' expectations or desire for personal expression. Wakely and Riley (2011) posit further that new approaches to urban planning and management call for the use of and support incremental housing strategies as major components of integrated urban development. Housing transformations can be equally part of a housing development strategy, just like incremental housing.

\section{METHODOLOGY}

The paper interrogates house transformation by owners in Kampala, the capital city of Uganda, examining the reasons for the phenomenon, highlighting its nature, opportunities it offers, and options to formalise it and take advantage of some of these opportunities for the benefit of the community.

The work is based on desk research comprising of a review of studies carried out in various parts of the world on house transformation, mainly focusing on transformations undertaken in low-income countries. The paper also largely draws on the Master of Architecture thesis work undertaken in Kampala by Jennifer Nalubwama, where she was investigating the nature of Kampala's owneroccupied houses through a case study approach. The research covered 100 owner-occupied houses that had undergone or were undergoing transformation identified in the five divisions of Kampala. Questionnaires were administered to house-owners, and photographs and sketches were made for analysis.

The study identified used a purposive sampling method to identify research cases augmented with convenience sampling based on accessibility and willingness of house-owners to participate in the study. Interviews were conducted on the technical personnel involved in the design and construction of the houses, and on the personnel in Kampala Capital City Authority (KCCA) involved in the process of house plans approval. Descriptive and context analysis techniques were used to analyse the data collected.

\section{RESULTS AND DISCUSSION}

\section{Causes of House Transformations in Kampala}

In recent times, several transformations are popular in Kampala's housing landscape and it is easy for one to assume that these transformations arise out of dissatisfaction with the existing housing conditions. In different settings, diverse reasons may induce house transformations. For example, unlike in Wokingham, England, Gosling et al. (1993) found that extensions appear less likely to be triggered by specific life-cycle events, like increases in household size or income, in Uganda, the opposite is observed (Nalubwama, 2018).

Most house transformations carried out in Kampala are not permissible by law. In addition, many developers do not attempt to secure permits to legalise these changes. At the same time, planning authorities in Kampala tend not to embrace house transformations easily as they see them as processes that increase the growth of slums. Under the National Physical Planning Act, 2010, the Physical Planning Board may approve alterations to buildings with or without conditions. While this may seem to be acceptable, the Board rarely gets to consider and accept many of the changes made to the houses in Uganda. Hence, many changes end up being illegal. In some cases, owners undertake changes/alterations that turn the structure unsafe for the occupants, thus calling for guidelines of how a developer can handle such changes safely.

Research findings in Kampala's five divisions revealed that $70 \%$ of homeowners never sought formal approval for their developments and $90 \%$ of homeowners never considered seeking this approval for their constructions even though it is a requirement. They claimed that the approval process was costly, frustrating, cumbersome, unnecessary, and some were not aware of the need to seek approval. They accused KCCA of being insensitive to people who have limited resources 
and have to build their houses in an incremental way (Nalubwama, 2018).

The Kampala study revealed that there are four main causes of house transformations in Kampala: the need for extra space, the need to increase household incomes, the desire to modernise the house to raise the status and to improve the functionality and aesthetics of the house (Nalubwama, 2018).

\section{The Need for Extra Space}

House owners often transform their houses when in need of extra space as families grow in number, when they acquire more property with time and when they need more space for tenants. This change in size and composition of households tends to cause additive house transformations involving the creation of more sleeping spaces, rarely accompanied by supporting spaces like toilets and bathrooms. The transformation may take vertical or lateral growth. Figure 1 shows the addition of rooms by the respective owners.

\section{Figure 1: Additions of rooms in Rubaga}

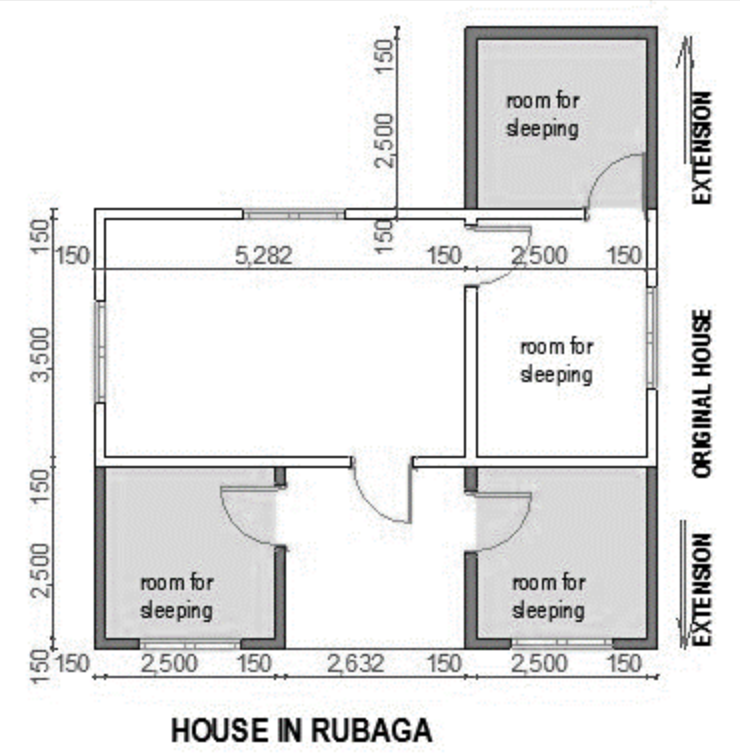

Source: (Nalubwama, 2018)

\section{The Need to Increase Household Incomes}

Some house-owners undertake transformations of their houses owing to the need to add rental space for home-based enterprises or rent as a way of raising extra income. The increased incomes mean that house-owners now have access to the muchneeded finance, which in turn helps in the commencement of new works or resumption of phased house transformations, or even hiring of professionals from the building industry. It is quite common in Kampala to see a new part of the house superimposed on the old garage as shown Figure 2 or of a house converted into a shop or rental accommodation for income generation as indicated in Figure 3.

Figure 2: A new housing unit superimposed on the original house

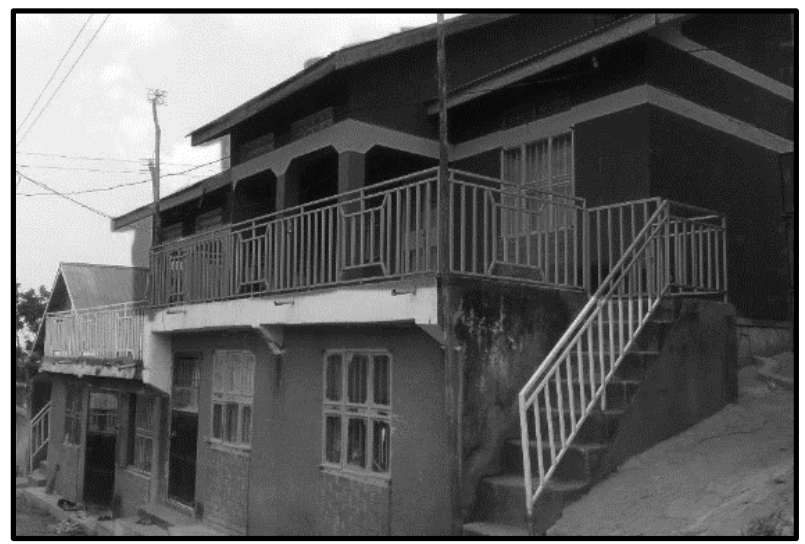

Source: (Nalubwama, 2018)

Figure 3: Garage room for a car transformed into a rental space

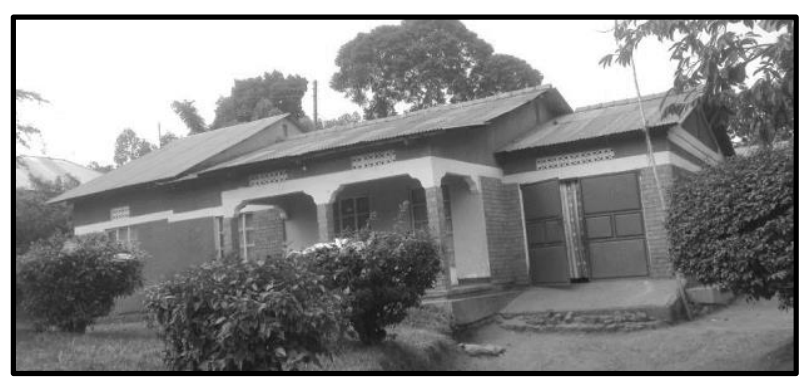

Source: (Nalubwama, 2018)

\section{The Desire to Modernise and Raise Status}

Some homeowners transform their houses due to peer pressure or the need to modernise their houses as part of the ways of raising their 'status and class' in society. Those who modernise their houses often do it through the use of modern materials, vertical 
extensions and provision of luxurious spaces. In this way, the houses are a means to communicate changes in status and class, resulting in an improvement of house forms. This also reveals a strong link between improvement/increase in the house-owners' incomes and house transformation. Figure 4 shows one of such houses where the owner is gradually modernising his structure.

Figure 4: House undergoing a horizontal and vertical transformation

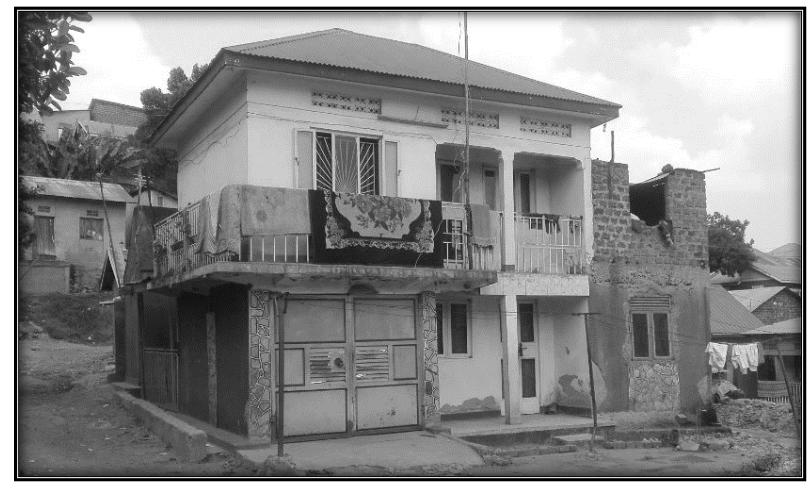

Source: (Nalubwama, 2018)

\section{The Need to Improve the Functionality and Aesthetics of the House}

The Kampala study revealed a strong link between local builders and house-owners that fuels the informal processes of housing construction. Often times, these houses are designed by local builders who lack the required skills to handle the process. The local builders also lack sufficient knowledge related to function, aesthetics and construction costs. As a result of the informal processes houseowners go through to develop their houses, they often occupy houses before their full completion and are left unsatisfied with the house design and resultant physical form. Once occupied, the houseowners then start house transformation aimed at improving their house satisfaction, as shown in Figure 5.
Figure 5: A new storied unit semidetached to the original house

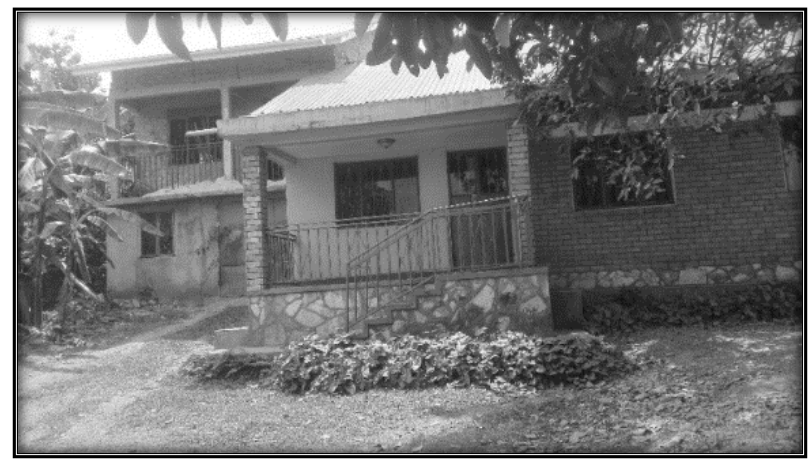

Source: (Nalubwama, 2018)

\section{Other Factors}

The above factors are the major causes of house transformation as revealed by both quantitative and qualitative data findings. The research also revealed that embedded in these causes were two additional drivers of transformations namely; the perceived and exercised exclusive rights owners have over their houses and land, and the freedom to carry out the house transformations (Nalubwama, 2018; Nakatudde, 2010).

\section{Nature of House Transformations in Kampala}

Research on house transformations in Kampala revealed that freedom to change and the exclusive ownership rights over land and house do not only result in house transformations but also inform the nature of transformations carried out. All income categories carry out house transformations. Transformations take place on both legal and illegal structures. Legal houses are those where the houseowner sought formal approval from the Kampala Capital City Authority (KCCA) while the illegal structures are one's built-in ignorance or total disregard of the legal requirements of KCCA (Nalubwama, 2018).

While the desire for luxury and display of changing status drives house transformations among high and middle-income households, basic function or financial needs tend to drive the changes among poorer households. They are characterised by physical and non-physical alterations to house form. Non-physical alterations are those involving a day-to-day change in space functions due to re- 
organisation of furniture, partitions and activities and or "colonisation" of adjacent spaces. The physical alterations are characterised by external, internal, lateral and vertical alterations of spaces or elements, subdivisions of spaces, or a combination of all. The study further reveals that transformation takes place mainly after house occupation. This is irrespective of whether the house construction is complete or not. As many of the houses have no properly developed designs, house transformations many times start during the construction phase. Developers may use rudimentary sketches to start house construction and along the way, they make changes to the houses according to the needs that arise. In other cases, changes in house construction finance house transformations. Most of these changes take place during the night, on public holidays or weekends when law enforcement personnel are not on the lookout for illegal construction going on (Nalubwama, 2018).

The transformations take place on all house types. They vary in size and may take simple or complex forms. All income categories undertake transformations in the area. Most transformations made are illegal as they rarely conform to the official requirements of the local bylaws of Kampala Capital City Authority. In addition, developers prefer avoiding spending money on the plan alteration fees. Nonetheless, house owners carry out transformations irrespective of whether they have formal or informal land and houseownership rights. With the ever-on-going transformations for long periods and at different times, a number of neighbourhoods end up looking like construction sites with abandoned structures.

In sum, housing transformations can be a viable option for increasing housing supply in situations of scarce resources, high demand and acute shortage of housing (Hamdi, 1995). Through alterations or extensions, these transformations help to meet the housing needs of many households in need of housing. Done on a larger scale, house transformation can contribute significantly to addressing the housing challenges in many developing countries (Beattie et al., 2010; Olima \& Onyango, 2010).

\section{CONCLUSION}

House transformation in Kampala offers several opportunities to the various stakeholders in the housing sector and the community as a whole. Through house transformations, homeowners develop home-based enterprises and rental housing thereby improving their incomes while contributing to an increased supply of housing. Through transformations, house-owners provide themselves housing, increase and improve on existing stock while meeting their needs. The processes of house transformation are largely informal, using traditional/local house construction means, materials and improvisation. They provide an opportunity to learn and preserve traditional building techniques, materials and methods that are gradually disappearing.

House transformation is inevitable in Kampala for the near future. The popularity of house transformations means that there is an opportunity to increase on and legalise some of the existing housing stock, and for local authorities to obtain additional revenue if KCCA were to carefully consider, accept, guide and formalise these processes. To this end, professionals in the building industry can intimately work with the house developers and local builders to improve the delivery of decent and legal housing for the community. At the same time, the interaction of the various stakeholders would help the transfer of skills and knowledge on the construction processes among the parties involved. Local authorities in Uganda are the custodians of the housing development processes in their respective areas of jurisdiction. They should work towards the development of guidelines for phased construction as a legal process. These guidelines should take into account issues of safety, security and aesthetics. Professionals such as architects and engineers should actively get involved in the design and supervision of the construction of phased housing as a way of getting more involved in community efforts of housing provision for all income categories. They should take advantage of the flexible nature of phased housing and the opportunities it offers to serve better the community. 


\section{REFERENCES}

Aduwo, E. B., Ibem, E. O., \& Opoko, A. P. (2013). Residents' Transformation of Dwelling Units in Public Housing Estates in Lagos, Nigeria: Implications for Policy and Practice. International Journal of Education and Research, 1 (4), 1-20.

Barry, J. E. (2008). Everyday Habits and Routines: Design Strategies to Individualise Home Modifications. Washington.

Beattie, N., Mayer, C., \& Yildirim, B. (2010). Incremental Housing; Solutions to meet the Global Urban Housing Challenge. Global University Consortium. Rio De Janeiro: UN World Urban Forum.

Gosling, J. A., Keogh, G., \& Stabler, M. J. (1993). House extensions and housing market adjustment: a case-study of Wokingham. Urban Studies, 30(9), 1561-1576.

Government of Uganda. (2010). Physical Planning Act, 2010. UPPC, Entebbe.

Hamdi, N. (1995). Housing without Houses: Participation, Flexibility, Enablement. London: Intermediate Technologies Publications Ltd.

Kallus, R., \& Dychtwald, S. (2010). Effects of User-initiated Extensions in Government-built Housing on the Urban Space: The Case of the Rambam Neighbourhood in Tirat Carmel, Israel. Journal of Urban Design, 15(1), 69-90.

Mirmoghtadaee, M. (2009). Process of House Transformation in Iran. Journal of Construction in Developing Countries, 14(1), 69-73.

Mukiibi, S. (2020). Housing provision in an environment of rapid urbanisation: a case of Uganda. International Journal of Social Science and Technology, 5(1), 1 -13.

Nakatudde, R. (2010). Real estate development, land tenure and land value dynamics in the Periurban areas of Greater Kampala City. Master's Thesis. Makerere University.

Nalubwama, J. M. (2018). An investigation into the nature of Kampala's owner-occupied houses.
Kampala, Uganda. Unpublished Masters dissertation. Makerere University

Nguluma, H. (2003). Housing themselves: Transformations, modernisation and spatial qualities in informal settlements in Dar-esSalaam, Tanzania. Doctoral thesis. Department of Infrastructure, Division of Urban Studies Royal Institute of Technology, Sweden.

Olima, W. H., \& Onyango, M. O. (2010). Housing Transformations in Nairobi, Kenya: A Strategy Towards Sustainable Urban Development. Conference on Technology \& Sustainability in the Built Environment, Nairobi, Kenya, 859876.

Popkin, S. J., Cunningham, M. K., \& Burt, M. (2005). Public housing transformation and the hard-to-house. Housing Policy Debate, 16(1), 124.

Tipple, G. (1999a). Extending Themselves: User Initiated Transformations of Government-Built Housing in Developing Countries. UK: Liverpool University Press.

Tipple. G. (1999b). Transforming Government Built Housing. Lessons for Developing Countries. Journal of Urban Technology, 6(3), 17-35.

Wakely, P. and Riley, E. (2011). The case of incremental housing. Cities Alliance Policy Research and Working Paper Series No. 1. The Cities Alliance, Washington, D.C. 